\title{
The power of language tests in Turkish context: A critical study
}

\author{
Tuçe Öztürk Karataş ${ }^{a *}$ (iD), Zuhal Okan ${ }^{\text {b iD }}$ \\ ${ }^{a}$ Çukurova University, Education Faculty,ELT Department, Adana 01330, Turkey \\ ${ }^{b}$ Cukurova University, Education Faculty, ELT Department, Adana 01330, Turkey \\ APA Citation: \\ Öztürk Karataş, T., \& Okan, Z. (2019). The Power of Language Tests in Turkish Context: A Critical Study. Journal of Language and Linguistic \\ Studies, 15(1), 210-230. \\ Submission Date: 01/08/2018 \\ Acceptance Date:15./11/2018
}

\begin{abstract}
High-stakes tests are often introduced to bring about change on educational practices and thus lead to pedagogical reform. The Field Knowledge Test (FKT) for teacher candidates of English in Turkey is an example of such an attempt. This study aims to giving voice to English language teacher educators and student teachers to view the FKT critically to investigate if it has brought about the intended changes and its impact on its main stakeholders. The study, first, presents Critical Language Testing (CLT). Then, it gives information on the context of the study. Data collection for the study involved 153 test takers and 23 teacher educators working at ELT Departments in Turkey. Two open-ended questionnaires were used to survey participants' perceptions of the FKT in terms of its impact on the nature of education they receive, their attitudes and feelings and also on their academic and personal lives. Analysis of data paved the way for further studies on how high stakes tests might or might not be efficient agents of change in various educational contexts.
\end{abstract}

(C) 2019 JLLS and the Authors - Published by JLLS.

Keywords: the use of test; the power of test; impact and consequences of test

\section{Introduction}

There is no doubt that tests do have a very influential role in our lives, especially when an educational system is based on standardised tests. It has been commonly assumed that high-stakes tests in particular, could exert a desirable influence on educational practices and thus promote curricular and pedagogical reform (Madaus, 1988; Luxia, 2005). That is why, changing the language testing policy by introducing a new standardised test to produce change is a widely traced practice in the world (Luxia, 2005; Shohamy et al., 1996). Although not explicitly stated, as in Turkish context, language tests can be introduced in a top-down manner. Most of the change in language testing policy is conducted without any explicit discussion on their uses, and in most cases they are believed by public to be independent from social and political contexts (Menken, 2008). However, though these tests are used mainly to determine test takers' language achievement, they might also have the potential to change the lives of students and teachers and society at large.

The early studies on the impact of tests used a relatively new concept, 'washback' or 'backwash' to describe the positive and negative consequences of tests on teaching and learning (Hughes, 2003).

\footnotetext{
${ }^{*}$ Corresponding author. Tel.: +90-322-338-6355

E-mail address: tozturk@cu.edu.tr
} 
'Washback' is defined in the words of Cheng and Curtis (2004) as a term "rooted in the notion that tests or examination can or should drive teaching, and hence learning" (p.4).Therefore, tests can have consequences which refer to their intended or unintended and positive or negative effects on teaching, learning, students, teachers, and school (Cheng, 2008).

Since the late 1980s, the discussion on washback mostly focused on the question of "does washback exist?". In an attempt to capture the essence of washback, some scholars looked into the quality of washback and concluded that most high-stakes tests produced negative washback effects (Bracey, 1987; Stake, 1991) while others analysed how the scope of the test has influenced the educational system as a whole (Bailey, 1996; Wall\& Alderson, 1993). Although now there seems to be no doubt that washback exists, the debate still seems to be far from reaching an agreement on which factors result in change and which factors promote positive or negative change and effects in a certain testing context.

Recently, awareness of this complex nature of the phenomenon of test impact shows that simply changing the test or introducing a new test does not guarantee a direct and desirable change in the educational context and society at large (Alderson\&Hamp-Lyons, 1996;Andrews, Fullilove\& Won, 2002).They might have highly hazardous consequences due to their possibility to generate test power on individuals in the context of testing. In an interview, Alderson explains that "I don't think washback is necessarily caused by the test. It is the use or misuse of the test... What is important is who uses the test and how they use it, and whether it is used for high or low stakes" (Brunfaut, 2014, p.112-113). That is to say, the declared purpose of the tests and their actual use can differ. As Shohamy (2001b) puts it, "there was an official story and real story. The official story was that tests were used for educational purposes, to measure knowledge, while the real story in a large number of cases was that the tests were used as a means of achieving certain objectives" (p.xii).

In recent years, looking for the 'real stories' of the tests by examining them in their own contexts has increasingly gained popularity. Shohamy's works $(1998,2001 \mathrm{~b})$ on CLT, for example, focus on tests within the view of their social, cultural, educational and political contexts in order to identify their consequences, roles and impact on individuals. The basic premise is to enhance the test takers' social reflectivity and awareness by questioning tests in terms of power, implications, fairness, uses, and impact together with social and ethical responsibilities.

\subsection{Critical language testing: The power of tests}

The past ten years have seen a growing awareness that testing can move beyond the concerns over reliability and validity issues in language assessment. One such attempt is CLT which views tests as the vehicles related to political, educational and social domains rather than just as a tools assessing knowledge, skills or progress. In other words, CLT locates the language testing field on the root of critical pedagogy which is concerned with practices producing power relations advantaging some over others in society (Shohamy, 1998; 2001b; McNamara \&Roever, 2006).

Due to the power relations embedded in the testing contexts, CLT does not regard language tests as neutral acts (Shohamy, 1998). In fact, to McNamara (2005), "All language testing is potentially political; it can be associated with, and operate in the service of power and control" (p.368) mainly because tests have the potential to be used by the testers in authority to change individuals, institutions, systems and society at large. Inevitably, such potential might result in tests imposing some changes in the behaviours of tests takers and making them 'the instruments of power' (Shohamy, 2001a, 2001b)

CLT argues that tests are often introduced by powerful organizations attempting to manipulate and control educational systems according to set agendas (Shohamy, 2007a, 2007b). This feature of tests allots power to tests because in most of the testing contexts, who determine what to test, how to test, how to score, how to administer and determine results is testers who hold the power. According to CLT, 
these circumstances create nonnegotiable and continuous control over discourse of tests. As Van Dijk (2008) points out, "Those who control discourse may indirectly control the minds of people. And since people's actions are controlled by their minds (knowledge, attitudes, ideologies, norms, values), mind control also means indirect action control (p.9)". When granted such power, tests and testers can control directly or indirectly the knowledge and behaviours of tests takers and society at large. When tests are used for crucial functions such as passing a class, attending a university, taking a job, getting degree etc., in particular, then, they become powerful turning points in test takers' lives (Bourdieu, 1991). Inevitably, with such high stakes implications, the power of tests emerges.

However, testers are not the only ones who create the power of tests. As Young (2012) explains, power is "co-constructed by all participants - both the powerful and the non-powerful... Non-powerful participants co-construct power by accepting the constraints imposed upon them" (p.185). Thus, it is the test takers who assign unlimited power to testers (Bourdieu, 1991; Shohamy, 2001b).

What makes a single test powerful also depends on the meaning individuals attribute to tests, which often results in changes in the behaviours of individuals and society. When individuals are judged on the basis of their performances on a single test, this test turns into a powerful tool. Test takers then adopt behaviours in accordance with the demands of the test as they fear detrimental effects they can have on their lives. In her analysis of the narratives obtained from test takers, Shohamy (2001b) states that:

Test takers learn that in the testing game there are rules to follow, even if they are not rational and make no sense. Test takers know that the best strategy for a tester is to comply with and follow the testing rules- no questions asked (p.11).

Thus, CLT encourages test takers to view tests critically to question their uses and function in their lives for the development of more democratic testing practices (Shohamy, 2001b). However, very little attention is given to questioning the uses of tests and examining their power, intentions, effects, consequences and roles in education and society from the perspective of individuals who are exposed to tests (McNamara\&Roever, 2006). In fact, this is what our study attempts to do: listen to the voices of student teachers of English and ELT educators in Turkish context.

\subsection{Studies on impact of tests in Turkey}

Turkish national education system is mostly test-oriented. Therefore, it is not surprising to find studies focusing on how high-stakes tests impact students, teachers, and educational system at large (Yıldırım,2010; Özmen 2011a, 2011b; Yavuzer\&Göver, 2012; Akpınar\&Çakıldere, 2013; Hatıpoğlu, 2016; Külekçi, 2016; Sayın\& Aslan, 2016). Most of these studies deal with washback effect of the tests in Turkish context and examine it in such domains as"instructional methodologies and teaching strategies, and student attitudes and perceptions about exams" (Toksöz\&Kılıçkaya, 2017; p.186). The exams highlighted in these studies are the national high stakes tests administered by ÖSYM (Measurement, Selection and Placement Center). The general consensus of these studies is that the emphasis on the recognition skills with multiple-choice questions makes the stakeholders ignore the productive skills and the receptive skill of listening. They point out that these tests might turn to barriers to test takers' future personal and professional lives and affect their psychology negatively.

Additionally, a review of these studies reveals unsettled and frequently changing nature of test system in Turkey. As Hatipoğlu (2016) puts it, "every change related to the testing system in a country has complex impact in a number of directions on its educational system" (p. 142).

Accordingly, Toksöz and Kılıçkaya (2017) highlight the importance of focusing on test takers' views and suggestions about these tests. In fact, this is what our study attempts to do: listen to the voices of 
English language teacher educators and student teachers to view the FKT critically to investigate its influence on test takers' personal and academic lives. The FKT is offered to thousands of language teacher candidates to get appointed in the schools of Ministry of Turkish Education. However, there are few studies conducted to examine its power and impact in Turkish context. This study is an attempt to do that.

\subsection{Research questions}

With this aim in the mind, this study tries to find the answer to the following questions:

1. Are ELT educators and students teachers familiar with the content and format of the FKT?

2. Is there an alignment between the FKT and the curriculum of ELT departments?

3. Is there any impact of the FKT on education offered in ELT departments?

4. Is there any impact of students' out of class studies for the FKT on ELT classes according to the educators?

5. What are the ELT educators and student teachers' attitudes towards the FKT?

6. What is the meaning of the FKT for the student teachers?

7. Are there any unintended consequences of the FKT for ELT educators and student teachers?

8. Are there any suggestions of the participants to improve the FKT? If so, what are they?

\section{Method}

\subsection{The Context}

Turkey has a central education system where The Ministry of National Education (MEB) is responsible for all types of education, with one exception: higher education, which falls under the Council for Higher Education (YÖK). Education in Turkey is compulsory from ages 6-14. At each level of the system, the performance of the students, teachers and even schools is evaluated by looking at how well students perform on various standard exams (Hatipoğlu, 2016).

High stakes exams in Turkey are prepared and administered by the Student Selection and Placement Centre (OSYM) which is a very powerful organisation. One such high-stakes exam is the University Entrance Exam (UEE) which is a two-stage exam: Students first sit for the Transition to Higher Education Examination (YGS).Students with sufficiently high scores are then allowed to take the Undergraduate Placement Examination (LYS). The number of Turkish students who sit for the admissions examinations has grown considerably in recent years and exceeds the number of available seats at Turkish universities. In 2017, more than 2.2 million students sat for the YGS examination. As the numbers indicate, placement in university programs is competitive and based on test performance. Teacher training departments are no exception in terms of competition as thousands of new graduates of Faculties of Education expect to be employed by the State according to their scores from the national tests administered annually: the KPSS (Public Personnel Selection Test) with several sub-tests. Initiated by ÖSYM in 2002, the KPSS procedure has served as the main criterion for the selection and recruitment of teachers. In 2013, however, the FKT has been introduced as a new sub-test of the KPSS on the premise that while the other sub-tests of the KPSS tested teacher candidates for their knowledge in educational sciences as well as world knowledge, the FKT focused on assessing whether teacher candidates are competent at their specific fields. 
The FKT for teacher candidates of English is a national high-stakes test that includes two major parts called subject matter knowledge (English language proficiency 50\%, Linguistics 16\%, and Literature $14 \%)$ and subject-specific pedagogical knowledge (20\%). Language of the test is English and it is comprised of 50 multiple-choice questions with some grammar, vocabulary and reading questions. This national test does not offer any sections or items for listening, speaking and writing. Although the test has been in operation since 2013, insufficient research has been done to investigate its use and effects on individuals in Turkish context.

\subsection{Participants}

A total of 23 members of staff at ELT Departments and 153 student teachers took part in the study from three different state universities in Turkey. The ages of the educators range from 30 to 55. They have more than ten years of teaching experience. Most of them are female. And an overwhelming majority $(\mathrm{N}=20)$ has got $\mathrm{PhD}$ degrees while the rest have MA degrees.

As for the student teachers, their age vary from 20 to 25 . More than two thirds of the participants are female and the rest are male. All of the participant students are fourth year students and have declared their intention of taking the FKT when the academic year ends.

\subsection{Data Collection and Analysis}

Two different open-ended questionnaires (see appendix A and B), each of which includes 13 questions were employed to collect data during 2014-2015 academic term. These open-ended questionnaires cover a range of issues related to the impact and power of the FKT. The development of the questionnaire started with reviewing the relevant literature and examining the questionnaires designed for similar purposes. After compiling relevant items for the Turkish context, we then constructed the first drafts and administered them to 30 student teachers and three educators. Following their suggestions we revised them and made the necessary changes.

As this is a mainly descriptive study, we opted for open-ended questions to gather more in-depth answers from our participants. A major concern for us is to examine how student teachers and educators make sense out of their experiences to understand what the participants are thinking and why they think what they do in terms of the impact and power of the FKT. To do so, content analysis was conducted. Though most of the data were presented qualitatively, due to the nature of some, we reduced some content to numbers.

Bearing the objectives of the study in mind, we read the answers, analyzed and put them into themes and sub-themes by coding. We came up with these themes and sub-themes:

1. Familiarity with format and content of the FKT,

2. Alignment between the FKT and the curriculum of ELT department

3. The impact of the FKT on
a. the syllabus used in ELT classes
b. the selection and use of ELT educators' teaching methods
c. the selection and use of materials in ELT classes

4. The impact of students' out of class studies for the FKT on ELT classes

5. The participants' attitudes to
a. validity and reliability of the FKT
b. The FKT as a selection tool
c. Content of the FKT 
6. The Meaning of the FKT for the student teachers

7. The Unintended Consequences of the FKT

8. Suggestions

The results are reported according to the above categories.

\section{Results and Discussion}

\subsection{Familiarity with Format and Content of the FKT}

One of the basic tenets of ethical testing practice is the issue of accountability. Test developers are expected to provide the test takers with information on test content and format, and that the test is relevant to their needs and interests (McNamara, 2014). When we asked our participants if this is the case with the FKT, they gave the following responses:

Table 1. Familiarity with format and content of the FKT

\begin{tabular}{|c|c|c|c|c|c|}
\hline \multirow[t]{2}{*}{ Theme } & \multirow[t]{2}{*}{ Codes } & \multicolumn{2}{|c|}{ Students } & \multicolumn{2}{|c|}{ Educators } \\
\hline & & $\mathbf{f}$ & $\%$ & $\mathbf{f}$ & $\%$ \\
\hline The familiarity with & Partially familiar & 130 & 85 & 15 & 65 \\
\hline the test & Not familiar & 23 & 15 & 8 & 35 \\
\hline
\end{tabular}

As seen in Table 1, $85 \%$ of student-teachers and the $65 \%$ of educators have expressed that they are familiar with the format and the content of the FKT in part while $15 \%$ of student teachers and $35 \%$ of educators have no idea about it. The extracts below express student teachers' opinions.

ST95: It includes 50 questions but even our teachers do not know much about the content. A test full of surprises, it seems.

ST14: I do have a general sense of the content.

ST73: We have not been informed at all.

These responses show that the OSYM fails to inform test takers on what is expected of them in the FKT. What is known is the number of the questions and the main subject areas of the test. OSYM occasionally displays sample questions, only a few, on its official website and some private publish materials for the preparation of the test.

\subsection{Alignment between the FKT and the Curriculum of ELT Department}

The second question of the questionnaires focuses on identification of the resemblance between the FKT and the curriculum of ELT department. Table 2 reports the responses.

Table 2. Alignment between the FKT and the curriculum of ELT department

\begin{tabular}{cccccc}
\hline \multirow{2}{*}{ Theme } & Codes & \multicolumn{2}{c}{ Students } & \multicolumn{2}{c}{ Educators } \\
\cline { 2 - 6 } & & $\mathbf{f}$ & $\mathbf{\%}$ & $\mathbf{f}$ & $\mathbf{\%}$ \\
\cline { 2 - 6 } $\begin{array}{c}\text { Alignment between the } \\
\text { FKT and ELT } \\
\text { curriculum }\end{array}$ & Partial Alignment & 105 & 69 & 8 & 35 \\
\cline { 2 - 6 } & No Alignment & 40 & 26 & 11 & 48 \\
\cline { 2 - 6 } & No idea & 8 & 5 & 4 & 17 \\
\hline
\end{tabular}


As seen in Table 2, 26\% of student teachers and $48 \%$ of educators state that the FKT does not comply with ELT department curriculum in Turkey. These numbers are quite significant in that they raise the question of content validity of the FKT. If the content of the test that is used to make a decision about whether a student teacher is eligible to be a language teacher does not align with the curriculum that the student is taught in the Faculty, then, there seems to be a big problem. Apparently, this is the case in our study because $69 \%$ of the student- teachers and $35 \%$ of the educators report that the content of the FKT does not fully but partially comply with the content of the ELT departments. Some of the student teachers say that:

ST25: The courses in our department are mainly practical in nature, so they are different from the test content.

ST141: Though the names of most courses seem to reflect the content of the test, in reality, they do not.

The following two extracts look at this issue from the educators' point of view.

E5: Although ELT departments offer a common program, contents of the courses vary according to the educators and the materials they use. What is considered relevant in one university may not be relevant in another.

E7: Not necessarily because although YOK imposes a unified programme for all Faculties of Education in Turkey, there might be differences in the implementation.

To some student teachers, it is not the content but the teaching methods used in the class do matter. Additionally, the student teachers who mention the existence of a partial alignment between the FKT and curriculum in the departments note that the content and the teaching methods the educators choose in the class do not match with the FKT. Some say that:

ST13: Even if we talk about a partial alignment in terms of content, how the teachers choose to teach is completely different.

ST44: Yes, partially similar but the points that our teachers prefer to focus on in the class are different from the test content.

\subsection{The Impact of the FKT on Education Offered in ELT Classes}

\subsubsection{The syllabus used in ELT classes}

Moved with the idea that tests can guide "test takers what they need to know, what they will learn and what they will be taught" (Shohamy, 2001b, p. 17), we asked our participants to express their opinions on the impact of the FKT on what is offered in ELT classrooms. The participants' responses are presented in Table 3:

Table3. The Impact of the FKT on the Syllabus of ELT Classes

\begin{tabular}{cccccc}
\hline \multirow{2}{*}{ Theme } & Codes & \multicolumn{3}{c}{ Students } & \multicolumn{2}{c}{ Educators } \\
\cline { 2 - 5 } & & $\mathbf{f}$ & $\mathbf{\%}$ & $\mathbf{f}$ & $\mathbf{\%}$ \\
\cline { 2 - 5 } Impact of the FKT on the & & 43 & 28 & 3 & 13 \\
\cline { 2 - 5 } syllabus of ELT classes & Partial impact & 110 & 72 & 20 & 87 \\
\hline
\end{tabular}

Table 3 shows that $87 \%$ of the educators and $72 \%$ of the student teachers report no impact of the FKT on their syllabus while $28 \%$ of the students and $13 \%$ of the educators acknowledge partial impact. These numbers clearly show that most of the educators prefer to stick with their own syllabus. However, 
considering that teaching to test content is not surprising in contexts where large-scale high-stakes tests exist (Shohamy, 1993; Smith, 1991), we aimed to understand whether educators do anything in the class to make student teachers familiar with the FKT. The results are presented in Table 4:

Table 4. Making students familiar with the FKT

\begin{tabular}{|c|c|c|c|c|c|}
\hline \multirow[t]{2}{*}{ Theme } & \multirow[t]{2}{*}{ Codes } & \multicolumn{2}{|c|}{ Students } & \multicolumn{2}{|c|}{ Educators } \\
\hline & & $\mathbf{f}$ & $\%$ & $\mathbf{f}$ & $\%$ \\
\hline Making students & doing something & 48 & 31 & 10 & 44 \\
\hline familiar with the test & doing nothing & 105 & 69 & 13 & 56 \\
\hline
\end{tabular}

Table 4 shows that more than half of the educators (56\%) prefer not to do anything in their classes for the FKT while $44 \%$ of them note that they do. They report paying attention to the major themes and terminologies likely to appear in test. One educator puts it in the following manner:

E7: I sometimes feel that, instinctively, I put more emphasis on terminology more than I used to...

E19: Sometimes I touch upon issues appeared in the test when they are related to my own topic.

Although the educators seem to be inclined to change some of their behaviours in their classes, $69 \%$ of the student teachers do not agree. In fact, they believe that the ELT educators ignore their needs and the reality they live in. Two student teachers said:

ST22: They do everything they can for us not to be successful at the exam.

ST61: I do not feel they do care at all. They give priority to their own assignments.

Based on these complaints of the student teachers, we asked student teachers whether the ELT courses make any contribution to their learning for the FKT and presented the results in Table 5:

Table 5. Contribution of ELT courses for the FKT

\begin{tabular}{cccc}
\hline Theme & Codes & \multicolumn{2}{c}{ Students } \\
\cline { 2 - 4 } & & f & \% \\
\hline Contribution of ELT courses to & & 48 & 31 \\
\cline { 2 - 4 } students learning for the FKT & Partial contribution & 105 & 69 \\
\hline
\end{tabular}

As seen in Table 5, a majority of the student teachers (69\%) say "No." In fact, it seems that they feel frustrated because, on the one hand, they are subjected to certain demands by the department, while on the other, they need to comply with what is required by the test itself. Thus, some of them regard the ELT courses in the department as hindrance due to their irrelevance to the test content:

ST1: They bombard us with the assignments not related to the test content. That limits the time we have to devote for the test.

ST35: This is our final year, final term at the Faculty. Courses should be made easier.

These results show that student teachers are demotivated to follow the courses offered in the department. They keep asking why teachers do not take the content of the test into consideration while preparing their syllabus. In fact, they argue that there is an urgent need for a common syllabus for all ELT departments in Turkey designed to comply with the requirements of the FKT.

ST115: If there were one unified syllabus, we wouldn't have to study for the courses in the department and the FKT at the same time. We wouldn't try to find a balance between these two different poles. 
What is clear from these comments is that the power of the test inevitably creates a tension between the educators and student teachers. While student teachers expect their teachers to respect their needs, educators seem not to be willing to do so. Thus, we look for whether the student teachers demand any modification on their syllabus according to the content of the FKT. The results are presented in Table 6:

Table 6. Students' demands to modify the syllabus

\begin{tabular}{|c|c|c|c|c|c|}
\hline \multirow[t]{2}{*}{ Theme } & \multirow[t]{2}{*}{ Codes } & \multicolumn{2}{|c|}{ Students } & \multicolumn{2}{|c|}{ Educators } \\
\hline & & $\mathbf{f}$ & $\%$ & $\mathbf{f}$ & $\%$ \\
\hline \multirow{2}{*}{$\begin{array}{l}\text { Students' demand to modify the } \\
\text { syllabus according to the FKT }\end{array}$} & Demanding modification & 125 & 82 & 12 & 52 \\
\hline & Demanding no modification & 28 & 18 & 11 & 48 \\
\hline
\end{tabular}

An overwhelming percentage ( $82 \%$ ) of the student teachers demands a change. It seems that $52 \%$ of the educators are in fact aware of this expectation. The following quotations illustrate student teachers' demands:

ST41: Courses should definitely centre upon the test. We have got to be a teacher first, before being a good teacher.

ST35: If you fail in the FKT, what is the point of graduating from the Faculty?

ST69: Our whole life depends on this exam. They need to be aware of this.

However, knowing this gate keeping function of the FKT, some of educators strongly object to comply with this demand of student teachers. One says that:

E8: If I try to do everything they want, my lessons would transform into "Erkan FKT" courses.

And I am strongly against that.

\subsubsection{The selection and use of ELT educators' teaching methods}

As seen in Table 7, $68 \%$ of the student teachers and $87 \%$ of the educators state that the FKT has no impact on the methods used by the educators in the class while $32 \%$ of the students and $13 \%$ of the educators express a partial impact.

Table 7. The Selection and use of teaching methods

\begin{tabular}{|c|c|c|c|c|c|}
\hline \multirow[t]{2}{*}{ Theme } & \multirow[t]{2}{*}{ Codes } & \multicolumn{2}{|c|}{ Students } & \multicolumn{2}{|c|}{ Educators } \\
\hline & & $\mathbf{f}$ & $\%$ & $\mathbf{f}$ & $\%$ \\
\hline Impact of the FKT on the & Partial impact & 49 & 32 & 3 & 13 \\
\hline $\begin{array}{l}\text { selection and use of teaching } \\
\text { methods }\end{array}$ & No impact & 104 & 68 & 20 & 87 \\
\hline
\end{tabular}

Most of the educators add that adopting teaching methods that would support the FKT is not their responsibility. One teacher says:

E11: We are training EFL teachers. This is what we are supposed to do. We are not preparing them for that specific exam.

To some of the student teachers, the reason for the unwillingness of the educators is that every teacher has her/his own teaching style and does not compromise on that. The following excerpts display student teachers' frustration and dissatisfaction with the educators' resistance to comply with the test's requirements. They no longer try to rationalize educators' stance but demand change.

ST22: They have to stop giving us assignments and start teaching test-based content. 
ST18: Portfolio assessment or process-based evaluation has got nothing to do with the FKT. They take time and mean a big disadvantage for us.

\subsubsection{The selection and use of materials in ELT classes}

When asked about the impact of the FKT on the selection and use of materials in ELT classes 78\% of the educators and $75 \%$ of the student teachers state that they do not observe any effect of the FKT.

Table 8. The selection and use of materials in ELT classes

\begin{tabular}{|c|c|c|c|c|c|}
\hline \multirow[t]{2}{*}{ Theme } & \multirow[t]{2}{*}{ Codes } & \multicolumn{2}{|c|}{ Students } & \multicolumn{2}{|c|}{ Educators } \\
\hline & & $\mathbf{f}$ & $\%$ & $\mathbf{f}$ & $\%$ \\
\hline Impact of the FKT on & The partial impact & 38 & 25 & 5 & 22 \\
\hline $\begin{array}{c}\text { material selection and } \\
\text { use }\end{array}$ & No impact & 115 & 75 & 18 & 78 \\
\hline
\end{tabular}

Some educators vehemently oppose to introducing the FKT related materials in the class by noting that:

E1: I do not change my materials since I believe that the FKT is not a reliable test. It does not measure any quality learning.

E14: No, I don't and I don't have any intention to do so.

However, it should be noted that though most of the educators try hard to minimize the impact of the FKT on their material selection, some participants acknowledged limited use of multiple choice questions and exercises in ELT classes as the following extracts illustrate:

E7: Despite my total disagreement with multiple choice techniques, I sometimes feel the need to introduce such questions in the class so that they would be familiar with the format.

\subsection{The Impact of Students' out of Class Studies for the FKT on ELT Classes}

What is presented in the previous sections illustrates that a majority of educators resist the idea that the FKT has a power on how and what they teach in the classroom. They, in other words, try very hard not to lose control of what is going on in the classroom. However, inevitably perhaps, the power of the FKT, as a high-stakes test, might change the behaviours of those who are subjected to it. Our participants choose, for example, not to attend their regular classes at the Department, but get help from outside sources, namely private institutions. They spend their evenings and weekends going to these institutions and have to pay considerable amount of tuition fees. When asked how this situation affects their classes, $61 \%$ of the educators acknowledged that there is certainly an impact on how the classes are conducted.

Table 9. Students' out of class studies for the FKT

\begin{tabular}{|c|c|c|c|}
\hline \multirow[t]{2}{*}{ Theme } & \multirow[t]{2}{*}{ Codes } & \multicolumn{2}{|c|}{ Educators } \\
\hline & & $\mathbf{f}$ & $\%$ \\
\hline \multirow{2}{*}{$\begin{array}{l}\text { The impact of students' out of class } \\
\text { studies for the FKT on my classes }\end{array}$} & Yes & 14 & 61 \\
\hline & $\mathrm{No}$ & 9 & 39 \\
\hline
\end{tabular}

One, for example, is frustrated because student teachers bring some materials given to them in private courses into the classroom and ask her to verify some of the answers. What bothers them most seems to be the attitude of students to the courses in the Department. A majority of them feel that student teachers neglect the courses and their motivation is very low as the following extract illustrates:

E15: The test affects the way the students view my teaching. They want to be taught for the test rather than for their future profession. Attendance to the classes is low. Their motivation is low. 


\subsection{The Participants' Attitudes to the FKT}

\subsubsection{The issues of validity and reliability}

We have asked our participants, as they are the most interested group in the introduction of a new testing procedure, whether they think the FKT is a valid and reliable test. The responses are seen in Table 10:

Table 10. The validity and reliability of the FKT

\begin{tabular}{|c|c|c|c|c|c|}
\hline \multirow[t]{2}{*}{ Theme } & \multirow[t]{2}{*}{ Codes } & \multicolumn{2}{|c|}{ Students } & \multicolumn{2}{|c|}{ Educators } \\
\hline & & $\mathbf{f}$ & $\%$ & f & $\%$ \\
\hline \multirow{3}{*}{$\begin{array}{c}\text { Validity and Reliability of the } \\
\text { FKT }\end{array}$} & valid and reliable & 54 & 35 & $\begin{array}{c}--- \\
--\end{array}$ & ---- \\
\hline & not valid and reliable & 93 & 61 & 16 & 70 \\
\hline & no idea about it & 6 & 4 & 7 & 30 \\
\hline
\end{tabular}

Table 10 shows that an overwhelming majority of educators and student teachers (70\% and $61 \%$ respectively) question the reliability and validity of the FKT. As one educator puts it:

E15: Before a standard test is administered, it has to go through steps of validity and reliability checks. I believe the FKT doesn't meet the requirements.

This comment was echoed by a student teacher who said:

ST35:I do not think it is valid or reliable. In fact we have the evidence for it. In 2010 test results were tampered with.

Most of student teachers also complain about the number of the questions included in the test and the duration of the FKT. One of them commented that:

ST43:I don't think a test lasting just one hour can assess my field knowledge that I got through five-year education.

\subsubsection{The FKT as a selection tool}

Table 11 shows that $79 \%$ of the student teachers and $83 \%$ of the educators oppose the idea that the FKT functions as the main criterion for their entry to the profession.

Table 11. The FKT as a selection tool

\begin{tabular}{cccccc}
\hline \multirow{2}{*}{ Theme } & Codes & Students & \multicolumn{2}{c}{ Educators } \\
\cline { 2 - 5 } & & $\mathbf{f}$ & $\mathbf{\%}$ & $\mathbf{f}$ & $\mathbf{\%}$ \\
\hline \multirow{2}{*}{ The FKT as a selection tool } & Suitable & 32 & 21 & 1 & 4 \\
\cline { 2 - 5 } & Not suitable & 121 & 79 & 19 & 83 \\
\cline { 2 - 5 } & No idea & ---- & 3 & 13 \\
\hline
\end{tabular}

It seems that one main objection they have is to do with its content. They claim that the test fails to assess what it intends to assess, that is language proficiency, subject matter knowledge and subjectspecific pedagogic knowledge, all at the same time. Moreover, they state that the FKT leads test takers to adopt memorization as a main learning strategy:

E6: This exam is only based on recognition skills of teacher candidates. We should be able to assess productive skills such as oral $\&$ written performance of the candidates.

ST45: Even if you are not qualified for teaching and are not able to utter even a few sentences in English, you can be appointed as a teacher as long as you memorize the theoretical content.

In the following two quotations, student teachers question the system as an election process: 
ST140: I see no sense in taking such a selection test after all those years we spent to be a teacher. To be subjected to a test like that is simply irrational.

ST112: One single test should not determine whether we are eligible to be a teacher or not. After five years at the Faculty, I feel we are equipped enough with necessary qualifications.

\subsubsection{Content of the FKT}

The FKT, which is a knowledge test for the appointment of the new graduates, is expected to include all the required knowledge and skills for language teachers. We asked our participants if this is the case with the FKT. The responses are presented in Table 12:

Table12. The content of the FKT

\begin{tabular}{|c|c|c|c|c|c|}
\hline \multirow[t]{2}{*}{ Theme } & \multirow[t]{2}{*}{ Codes } & \multicolumn{2}{|c|}{ Students } & \multicolumn{2}{|c|}{ Educators } \\
\hline & & $\mathbf{f}$ & $\%$ & f & $\%$ \\
\hline \multirow[t]{3}{*}{ the content of the FKT } & Covering all knowledge and skills & 22 & 14 & 1 & 4 \\
\hline & Not covering all knowledge and skills & 128 & 84 & 16 & 70 \\
\hline & No idea & 3 & 2 & 6 & 26 \\
\hline
\end{tabular}

As seen in Table 12, $84 \%$ of the student teachers and $70 \%$ of the educators agree that the FKT does not cover all knowledge and skills required for an effective language teacher. They believe that the FKT neglects some skills and abilities entailed in teacher training. They put emphasis on the need to introduce a practical exercise or procedure including all teacher training skills and abilities because they believe that:

ST66: Being a teacher does not mean answering multiple questions. What is important is what you do in practice.

ST45: The test evaluates how good you are at memorizing. It should have a practical dimension.

\subsection{The Meaning of the FKT for the Student Teachers}

What we have presented so far illustrates that our student-teachers modify their behaviours in order to cope with the demands of the FKT. As we assume that the power of the test causes such a change because of the meaning they attach to it, we ask our student-teachers what the FKT exactly means to them. They mainly emphasize its gate keeping function.

ST90: I cannot start teaching if I fail in the test. My future depends on it.

ST65: It is almost a matter of life and death.

However, the student teachers also acknowledge that the power of the FKT will diminish once they become a teacher though now to them it is a handicap on the way to become a public servant. One teacher candidate said:

ST150: It has a temporary impact and significance. After I pass it, it will mean nothing.

\subsection{The Unintended Consequences of the FKT}

Tests might result in unintended consequences because of their potential power. Thus, we ask our participants whether the FKT has such an impact. 
Table 13. Impact of the FKT on the personal and academic lives of student teachers

\begin{tabular}{|c|c|c|c|c|c|}
\hline \multirow[t]{2}{*}{ Theme } & \multirow[t]{2}{*}{ Codes } & \multicolumn{2}{|c|}{ Students } & \multicolumn{2}{|c|}{ Educators } \\
\hline & & f & $\%$ & $\mathbf{f}$ & $\%$ \\
\hline \multirow{2}{*}{$\begin{array}{l}\text { Impact of the FKT on the personal } \\
\text { and academic lives }\end{array}$} & Impact & 132 & 86 & 23 & 100 \\
\hline & No impact & 21 & 14 & 0 & 0 \\
\hline
\end{tabular}

As seen in Table 13, all the educators and a majority of the student teachers believe that the FKT has an impact on their personal and academic lives. However, theypoint out that this impact is a negative one as they feel an enormous amount of pressure. They are aware that a high score on the exam is the only way to be assigned to a teaching post, which results in test-related anxiety. One student teacher says:

ST141: My whole life is affected. I feel dead inside.

This comment is echoed by an educator who says:

E7: I personally observe that they do not have any personal life at all. Whenever they have time, they run to private tutorials whether it is at night, after school or weekends. Most importantly, they live in a constant anxiety.

Both student teachers and educators maintain that the test damages students' intrinsic motivation and encourages them to focus on test performance instead of the learning process. They contend that an emphasis on learning for the sake of succeeding on tests discourages them from having a social life and hobbies.

ST147: This exam simply prevents me from enjoying my life and graduation from the Faculty. When asked whether the FKT has any impact on their personal and academic lives some educators state their concerns for the FKT by regarding it as an excuse for legitimizing commissioning ELT educators from other fields. They add that the very nature of how the test is constructed is inherently disempowering educators and reinforces the notion of worthlessness. One of the educators said:

E20: The FKT does not aim to standardizing and/or improving the quality of teachers and teaching but to create a power base for decision makers. Any support for such a testing and evaluation system fully controlled by inherently political bodies means ignoring the function, the presence and the identity of Faculties of Education and civil initiatives.

\subsection{Suggestions}

This section presents data on how the participants in our study perceive the FKT in general and if they advocate for any change in any part of the test.

Table 14. Need for change

\begin{tabular}{|c|c|c|c|c|c|}
\hline \multirow[t]{2}{*}{ Theme } & \multirow[t]{2}{*}{ Codes } & \multicolumn{2}{|c|}{ Students } & \multicolumn{2}{|c|}{ Educators } \\
\hline & & f & $\%$ & $\mathbf{f}$ & $\%$ \\
\hline \multirow{3}{*}{$\begin{array}{c}\text { Whether the FKT } \\
\text { needs to be improved } \\
\text { or changed }\end{array}$} & Need to be improved or changed & 125 & 82 & 19 & 84 \\
\hline & No need to be improved or changed & 21 & 14 & 2 & 8 \\
\hline & No idea on how it can be improved & 7 & 4 & 2 & 8 \\
\hline
\end{tabular}

Table 14 shows that $82 \%$ of the student teachers and $84 \%$ of the educators think that the FKT needs to be improved or changed, while $14 \%$ of the students and $8 \%$ of the educators do not think so. The call 
for changes in terms of the number of the questions and the content of the FKT was clearly articulated by student-teachers.

Their suggestions mainly aimed at addressing the consequences of their perceived and experiential inefficiency of the instrument since the test did not measure language performance consistently. The educators, on the other hand, raised issues related to the nature of teacher training programmes in Turkey in general. They pointed out that before any change in the FKT, a process of re-evaluation on how students are trained to become teachers should be implemented. Notably, however, very few participants from both groups demanded that the test should be abolished despite their concerns over the format and the content of the test as mentioned before.

One possible explanation might lie in Bourdieu's (1991) notion of symbolic power which he defines it as "It is a power which exists because the person submits to it believes that it exists" (p.192). One factor enhancing the symbolic power of the test is that the testing organisation is a very powerful institution (OSYM) which determines the knowledge included in not only the FKT but in numerous exams regularly administered in Turkey every year. The public often views the practice of the FKTnot negotiable or challengeable. One educator agrees that "It is controlled by a politically motivated central body. There is nothing that could be done about it. High stakes testing is 'high power' which 'top guys' hold."

\section{Conclusion}

The main objective of this study has been to give the student teachers and teachers of English a voice to the impact of the FKT in Turkish context. The findings reveal several issues that they are concerned about. One such issue is that student teachers feel they do not have adequate information on the content and the format of the FKT apart from the number of the questions that are going to be asked and its main subject areas. Though in traditional testing this might not be considered as a major concern, from CLT perspective, the tester is to make some information about the test accessible to test takers and society at large (Shohamy, 2001b). This means that OSYM needs to disseminate more information about the FKT in order to provide a more democratic testing context.

Additionally, considering content validity of the FKT, most of the student teachers do not think that the FKT fully comply with the content of the courses offered at the ELT departments in Turkey. In fact, despite its educational impact, most of the student teachers and educators do not think the FKT has any observable influence on the syllabus, the teaching methods and materials used in ELT classes in Turkey. It is due to the fact that most of the teacher educators appear to be doing nothing for making students familiar with the FKT. Some student teachers have also expressed that the ELT courses do not contribute to their learning for the FKT. That is why, they ask educators to modify the syllabus according to the FKT. However, most of the educators strongly object to comply with this demand of student teachers because they think that making them study for the FKT is not their job. In the FKT testing context, this tension between student teachers and educators make the student teachers neglect ELT courses and decrease their motivation to attend classes at the department.

This might be one of the reasons why student teachers believe that the FKT affects their out of class studies such as taking private tutoring for the FKT. Additionally, student teachers attribute to the FKT such a major meaning that can modify their behaviours. It means that the FKT has the potential to change the behaviour of student teachers even before its administration due to its gate keeping function.

In addition to this, both student teachers and educators agree that the FKT results in some unintended negative impact on the personal and academic lives of the student teachers in Turkish context. Since the FKT is believed to pave the way for a brighter future, student teachers spend a great amount of time and 
energy on practicing for the test. Furthermore, most of them think that preparing for the FKT has negative impact on the student teachers' social lives and psychological well-being as they feel themselves under a lot of pressure.

The results of this study also contribute further evidence to the attitudes of the student teachers and educators towards the FKT. Most of them believe that the FKT is not only unreliable and invalid but also unsuitable for the selection of the teacher candidates of English. According to them, it is because of the fact that the FKT does not cover all the knowledge and skills an English teacher needs to have. Moreover, they add that the FKT scores of the student teachers do not predict a true picture of their content knowledge for being an English teacher. Therefore, most of the participants draw attention to the need to change the FKT in a way that can improve its own testing context.

As shown by the results of the study, the FKT's primary function of selection of future teachers seems to impose more constraints on student teachers than on the educators. This selection function compels students to work for the immediate goal of getting good scores. In fact, they have come to consider studying for the test as their number one priority, and getting high scores in the test as an issue of life and death. In line with the previous studies (Rea-Dickins, Kiely \& Yu, 2007; Y1ldırım, 2010; Özmen, 2011a; 2011b; Yavuzer\&Göver, 2012) on the impact of tests in terms of affective factors, our study also explains how the FKT leads to intense levels of stress and anxiety for students given that all of their hard work over the years comes down to one test with partial awareness on its content and format. It is through their responses to open-ended questions that one can sense how the test affects their behaviours in many different ways. They point out they do not trust reliability and validity of the test and that it cannot truly reflect their actual knowledge as a prospective teacher. Yet, at the same time, being aware of the possible detrimental consequences of poor test results, they study for the test.

From educators' perspective, however, instead of shifting to the teaching of the FKT content, as was intended by the FKT constructors, most courses in ELT Departments still focus on their regular content because not much is known about the constructs measured by the FKT. Despite that, a number of educators acknowledge some kind of modification in their teaching methodology and selection of materials. This is surprising given the fact that crucial decisions are made on the basis of test results and when one's interests are seriously affected, who can afford not to teach to or study for the test? This is especially true when the sole measure of the success of the educational process in language teacher training being evaluated is the test scores. In fact, a number of studies (Davison, 2004; Hamp-Lyons, Hood, \& MacLennan, 2001) have shown that teachers usually find themselves in a dilemma over what they believe is best for their learners and what the system dictates them to teach. As they feel powerless, they tend to give up quickly and go with what the testing system requires them to do in order to help their students get familiar with the test content or format to gain successful results. Other studies (Cheng, 2001, 2005), concluded that tests did not influence teaching to a significant degree. They point to teachers' incomplete understanding of the nature of the exam, inadequate training, and professional backgrounds, which might lead them not to change methodologies as they probably do not know how to. Li's (2008) study also demonstrated that there was only a minor impact on teaching brought about by the China English Tests (CET); teachers did not change either what or how they instructed to any significant degree.

Educators in our case also represent a dissenting voice as they refuse to teach to the test. Their concerns around the reliability and validity of the test as well as its practicality and negative impact on students' academic and social lives might explain their position. In fact, these are the very issues that this particular study deem necessary to be addressed. In addition, we believe that the question as to whether the use of a test for other purposes, such as selection, will impede or facilitate the function of the same test as an agent for change should be raised. 
Considering the results, it needs to be noted that high-stakes tests are not specific to Turkey. They are observed in other parts of the world (e.g., Smith, 1991; Shohamy, 1993) where

tests are powerful and widely used tools, leading to high stake decisions for individuals, groups and political systems. Tests are implicated in multiple agendas - educational, social, economic and political. Similarly, in the context of language learning, it is often through language tests that policy makers are successful in introducing language policies that determine language priorities (Shohamy, 2007a, p.525)

What Shohamy argues above is particularly relevant in the case of Turkey where, as in many other countries, English is considered to be a vehicle for educational and occupational mobility. However, despite the high value attached to English and all the investments and efforts, there is widespread discontentment with the proficiency level of students. Therefore, authorities are in a constant search of ways to develop projects to teach English more effectively such as reforming English language curriculum and hiring native speakers of English to work with Turkish EFL teachers. In Turkish context, one such attempt is the introduction of the FKT for teacher candidates of English since this is the easiest and quickest way for policy makers to demonstrate action and authority. However, for a test to exert the intended effect it has to adopt test methods that also result in good learning exercises and applicable classroom practices (Pearson, 1988). Unfortunately, this is not the case in Turkey.

As a concluding remark we should note that the results of this study should be taken with some caution since they rely on self-report data from a questionnaire. Further empirical data is needed to obtain a richer understanding of the nature and scope of the impact of tests on teachers' and students' behaviours. An area for further research could involve the direct observation of classes in order to see the extent of intended or unintended consequences of the introduction of a high stake test in an educational setting. However, it can be concluded that we need to enhance the test takers' social reflectivity and awareness by questioning tests in terms of power, implications, fairness, uses, and impact together with social and ethical responsibilities. As in this case, one single test has the power to shape the future of test takers, can open and close doors due to the meaning attributed to the test by the individuals and society.

\section{References}

Alderson, J. C.,\&Hamp-Lyons, L. (1996). TOEFL preparation courses: A study of washback. Language Testing, 13(3), 280-297.

Akpınar, K. D., Çakıldere, B. 2013. Washback effects of high-stakes language tests of Turkey (KPDS and ÜDS) on productive and receptive skills of academic personnel. Journal of Language and Linguistic Studies, 9(2), 81-94. Retrieved fromhttp://dergipark.ulakbim.gov.tr/jlls/article/download/5000084297/5000078394

Andrews, S., Fullilove, J., \&Wong, Y. (2002). Targeting washback-a case-study. System, 30(2), 207 223.

Bailey, K. M. (1996). Working for washback: A review of the washback concept in language testing. Language testing, 13(3), 257-279.

Bourdieu, P. (1991). Language and symbolic power. Cambridge, MA: Harvard University Press 
Bracey, G. W. (1987). Measurement-Driven Instruction: Catchy Phrase, Dangerous Practice. Phi Delta Kappan, 68(9), 683-86.

Brunfaut, T. (2014). A lifetime of language testing: An interview with J. Charles Alderson. Language Assessment Quarterly, 11(1), 103-119.

Burrows, C. (2004). Washback in classroom-based assessment: A study of the washback effect in the Australian adult migrant English program. In L.Cheng\& Y. Watanebe (withA.Curis) (Eds.), Washback in language testing: Research contexts and methods (pp.113-128).Mahwah, NJ: Erlbaum.

Cheng, L. (2001). Washback studies: Methodological considerations. In Curriculum Forum (Vol. 10, No. 2, pp. 17-32).

Cheng, L.,\& Curtis, A. (2004). Washback or backwash: A review of the impact of testing on teaching and learning. In L.Cheng and Y. Watanabe (eds.) with A. Curtis (eds.), Washback in language testing: Research contexts and methods, (pp.3-17). Mahwah, NJ: Erlbaum.

Cheng, L. (2005). Changing language teaching through language testing: A washback study. Cambridge: Cambridge University Press.

Cheng, L. (2008). Washback, impact and consequences. In Encyclopedia of language and education (pp. 2479-2494). Springer US.

Davison, C. (2004). The contradictory culture of teacher-based assessment: ESL teacher assessment practices in Australian and Hong Kong secondary schools. Language Testing, 21(3), 305-334.

Hamp-Lyons, L., Hood, S., \& MacLennan, C. (2001). Promoting Quality Teaching in the Tertiary Context. Higher Education Review, 34(1), 60-76.

Hatipoğlu, Ç. (2016). The impact of the University Entrance Exam on EFL education in Turkey: Preservice English language teachers' perspective. Procedia-Social and Behavioral Sciences, 232, 136-144.

Hughes, A. (2003). Testing English for Language Teachers.

Li, H. (2008). Are teachers teaching to the test? A case study of the College English Test (CET) in China. Poster presented at $30^{\text {th }}$ Annual Language Testing Research Colloquim, Hong Zhou, China

Luxia, Q. (2005). Stakeholders' conflicting aims undermine the washback function of a high-stakes test. Language Testing, 22(2), 142-173.

Külekçi, E. 2016. A concise analysis of the Foreign Language Examination (YDS) in Turkey and its possible washback effects. International Online Journal of Education and Teaching, 3(4), 303-315. Retrieved from http://iojet.org/index.php/IOJET/article/view/141/143

Madaus, G. E. (1998). The influence of testing on the curriculum. Yearbook-National Society For The Study Of Education, 2, 71-112.

McNamara, T. (2005). 21st century shibboleth: Language tests, identity and intergroup conflict. Language Policy, 4(4), 351-370.

McNamara, T., \&Roever, C. (2006). Language testing: The social dimension(Vol. 1). John Wiley \& Sons.

McNmara, T. (2014).Language Testing. Oxford University Press. 
Menken, K. (2008). High-Stakes Tests as de facto Language Education Policies. In Encyclopedia of language and education (pp. 2529-2541).Springer US.

Özmen, K. S. (2011a). Analyzing washback effect of SEPPPO on prospective English teachers. The Journal of Language and Linguistic Studies, 7(2), 24-52. Retrieved from http://www.jlls.org/index.php/jlls/article/view/112/

Özmen, K. S. (2011b). Washback effects of the inter-university foreign language examination on foreign language competences of candidate academics. Novitas ROYAL (Research on Youth and Language), 5(2), 215-228. Retrieved from http://www.novitasroyal.org/Vol_5_2/OzmenKS.pdf

Pearson, I. (1988). Tests as levers for change. In D.Chamberlein\& R.J. Baumgardner (Eds.), ESP in the classroom: Practice and evaluation (pp.98-107). London: Modern English.

Rea-Dickins, P., Kiely, R., \& Yu, G. (2007). Student Identity, Learning and Progression: with specific reference to the affective and academic impact of IELTS on 'successful' candidates. IELTS Impact Studies Vol, 7. (IELTS Joint-funded research programme). IELTS Australia\&the British Council.

Sayın, B. A., Aslan, M. M. (2016). The negative effects of undergraduate placement examination of English (LYS-5) on ELT students in Turkey. Participatory Educational Research, 3(1), 30-39.

Shohamy, E. (1993). The Power of Tests: The Impact of Language Tests on Teaching and Learning. NFLC Occasional Papers.

Shohamy, E.,Donitsa-Schmidt, S., \&Ferman, I. (1996). Test impact revisited: Washback effect over time. Language testing, 13(3), 298-317

Shohamy, E. (1998). Critical language testing and beyond. Studies in educational evaluation, 24(4), 331-345.

Shohamy, E. (2001a). Democratic assessment as an alternative.Language testing, 18(4), 373-391.

Shohamy, E. (2001b). The power of tests: A critical perspective on the uses of language tests. Routledge.

Shohamy, E. (2006). Language policy: Hidden agendas and new approaches. Psychology Press.

Shohamy, E. (2007a). The power of language tests, the power of the English language and the role of ELT. In International handbook of English language teaching (pp. 521-531).Springer US.

Shohamy, E. (2007b). Language tests as language policy tools. Assessment in Education, 14(1), 117130.

Smith, M. L. (1991). Put to the test: The effects of external testing on teachers. Educational Researcher, 20(5), 8-11.

Stake, R. E. (1991).Impact of changes in assessment policy. In Stake, R.E., (ed), Advances in program evaluation: using assessment policy to reform education, Volume 1. London: JAI PressInc.

Toksöz, I., \& Kılıçkaya, F. (2017). Review of Journal Articles on Washback in Language Testing in Turkey (2010-2017). Lublin Studies in Modern Languages and Literature, 41(2).

Van Dijk, T. A. (2008). Discourse and power. palgrave Macmillan.

Wall, D.,\&Alderson, J. C. (1993). Examiningwashback: the Sri Lankan impact study. Language testing, 10(1), 41-69.

Yavuzer, H., Göver, Đ. H. (2012).Akademik personelin yabancı dil durumu ve yabancı dil sinavlarına 
bakış1: Nevşehir örneği [The academics' language proficiency and their views on foreign language exams: Nevşehir Example]. NEÜ Sosyal Bilimler Enstitüsü Dergisi, 1(2), 136-158.Retrieved from http://dergipark.ulakbim.gov.tr/nevsosbilen/article/download/1043000099/104300 0057

Yıldırım, O. (2010). Washback effects of a high-stakes university entrance exam: Effects of the English section of the university entrance exam on future English language teachers in Turkey. The Asian EFL Journal Quarterly, 12(2), 92-116.

Young, R. F. (2012). Social dimensions of language testing. The Routledge handbook of language testing, 178-193.

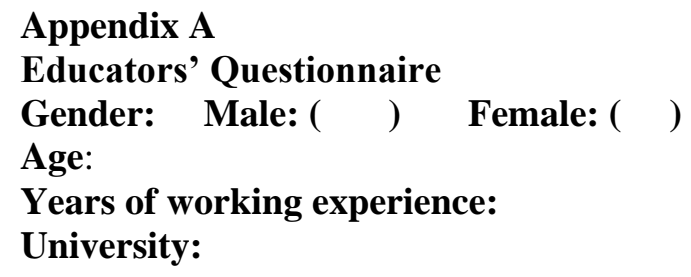

1. Are you, as a teacher of English, familiar with the format and content of the FKT? Please explain.

2. Do you think the content of the FKT complies with what is offered in ELT departments? Please explain.

3. Do you think the FKT affects the way you conduct your classes in terms of materials, syllabus and methods you use? How? Please explain
a) syllabus:
b) teaching methods :
c) materials:

4. Do you make use of exam-related materials to prepare students for the FKT? Why or why not? Please explain

5. Do you do anything in class to make your students familiar with the FKT? Why or why not? Please explain

6. Do your students demand any modification on your syllabus according to the content of the FKT? If yes, in what aspects? Please, explain.

7. Do you think your students' out of class studies for the FKT affect the way you teach in your classes? What aspects are mainly affected by it? Please explain.

8. Do you think that the FKT is a valid and reliable test? Why or why not? Please explain

9. Do you think that the FKT should be the main criteria for the appointment of new graduates of ELT departments as teachers of English? If yes, why; if no, why not? Please explain.

10. Do you think the content of the FKT covers all knowledge and skills required for an effective language teacher? If yes, in what aspects; if not, why not?

11. Do you think the FKT the FKT affects your students' personal and academic life? If so, how? Please explain.

12. Do you think the FKT has any effect on you as a teacher? Please explain.

13. Do you think the FKT can be improved or changed? If so, how? What are your suggestions? 


\section{Appendix B}

\section{The Student Teacher's Questionnaire}

Gender: Male: ( ) Female: $($ )

Age:

\section{University:}

Are you planning to take the FKT this year? ( )Yes ( ) No

1. Are you, as a student teacher of English and test taker of the FKT, familiar with the format and content of the FKT? Please explain.

2. Do you think the content of the FKT complies with what is offered in ELT departments? Please explain.

3. Do you think the FKT affects the classes in the Department in terms of materials, syllabus and teaching methods? How? Please explain
a) syllabus:
b) teaching methods :
c) materials:

4. Do your educators make use of exam-related materials to prepare student teachers for the FKT? Please explain

5. Do your educators do anything in class to make you familiar with the FKT? Please explain.

6. Do you think ELT courses contribute to your learning for the FKT? Please explain.

7. Do you demand any modification on the syllabus used in the Department according to the content of the FKT? If yes, in what aspects? Please, explain.

8. Do you think that the FKT is a valid and reliable test? Why or why not? Please explain

9. Do you think that the FKT should be the main criteria for the appointment of new graduates of ELT departments as teachers of English? If yes, why; if no, why not? Please explain.

10. Do you think the content of the FKT covers all knowledge and skills required for an effective language teacher? If yes, in what aspects; if not, why not?

11. What is the meaning of the FKT for you and your life? Please explain.

12. Do you think the FKT affects your personal and academic lives? If so, how? Please explain.

13. Do you think the FKT can be improved or changed? If so, how? What are your suggestions?

\section{Dil testlerinin Türkiye bağlamındaki gücü üzerine eleştirel bir çalışma}

\section{$\ddot{O} \mathbf{z}$}

Standart testler, eğitim uygulamalarında belli değişimler yaratmakla birlikte pedagojik reformları da beraberlerinde getirebilir. Testlerin bireyler ve toplum üzerinde oluşturduğu güç bu değişim ve etkinin temel kaynakları arasındadır. Farklı bağlamlarda bu testlerin bireyler üzerindeki gücünün ciddi sorunlara sebebiyet verdiği gözlemlenmektedir. Bu nedenle, literatürde bu testlerin ortaya çıkardığı etkileri anlayabilmek adına testlerin kendi bağlamları çerçevesinde eleştirel bir bakış açısıyla değerlendirmesi vurgulanmaktadır. 
Standart testlerin bireylerin hayatında etkin rol oynadığı ülkelerden birisi olan Türkiye'de son yıllarda uygulanmaya başlanan testlerden birisi Öğretmenlik Alan Bilgisi Testi (ÖABT)'dir. Ölçme, Seçme ve Yerleştirme Merkezi (ÖSYM) tarafından uygulanmakta olan bu sınavın etki ve sonuçları üzerinde yapılan çalışmaların az olduğu söylenebilir. Bu nedenle, bu çalışmada Türkiye bağlamında ÖABT'nin İngilizce öğretmen ataması için kullanılmasının İngilizce öğretmen adayları ve İngilizce öğretmenliği bölüm hocalarının üzerinde oluşturduğu etkileri belirlemek amaçlanmıştır.

Anahtar sözcükler: testin kullanımı; testin gücü; testin etki ve sonuçları

\section{AUTHOR BIODATA}

Tuçe Öztürk Karataş is a research assistant in ELT department at Çukurova University. She is conducting a doctoral dissertation on the use of tests as social practice.

Zuhal Okan holds a PhD from the University of Kent at Canterbury. She currently works as a Professor at Çukurova University, Faculty of Education, ELT Department. Her research interests include language assessment, discourse analysis and teacher education. 